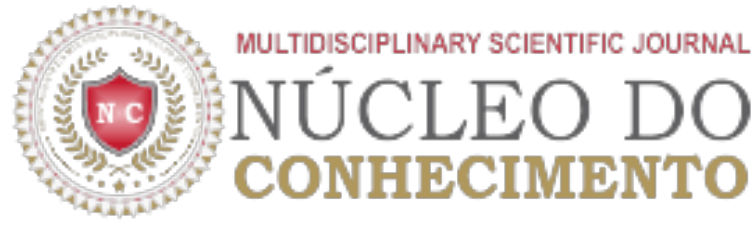

\section{Management of Costs in Public Administration: A Case Study at Hospital Colônia do Carpina - Parnaíba - PI}

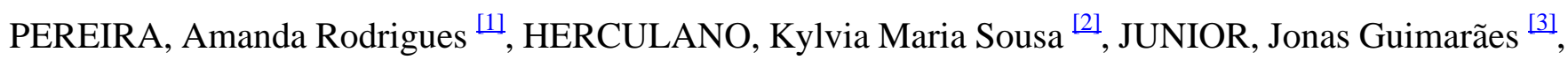
PUTRICK, Simone Cristina ${ }^{[4]}$, DENDASCK, Carla Viana ${ }^{[5]}$

PEREIRA, Amanda Rodrigues; et.al. Management of Costs in Public Administration: A Case Study at the Hospital Colônia do Carpina - Parnaíba - PI. Multidisciplinary Scientific Journal. Edition 08, Year 02, Vol. 05, pp. 121-143, November of 2017. ISSN:2448-0959

\begin{abstract}
The Fiscal Responsibility Law (LRF) requires that public entities manage public resources in a way that generates efficiency in the results of their activities, also demonstrates the importance of a System of Costs for Public Administration. The present study aims to analyze the use of a cost system as a managerial tool in the decision making process in public hospitals. The study shows the requirements of laws, as well as concepts and definitions, presenting the various forms of methods that are used by Cost Accounting to calculate and evaluate management results. This is an exploratory research, with a qualitative approach and a case study is carried out specifically in the accounting sector of the Hospital Estadual Colônia do Carpina (HCC). In the analysis it was observed that the instrument adopted at the hospital calculates the costs through a non-complex system which reduces the accuracy of the information used in the decision-making process. Finally, the work considers the importance that the RFL imposes on the public administration, in which it seeks the efficiency and transparency of public accounts.
\end{abstract}

Key words: Cost System, Public Administration, Cost Accounting.

\section{INTRODUCTION}

Cost accounting gives the manager information of strategic relevance to support decisions made within the entity. Hospitals have increasing health expenditures and due to the numerous functions performed in several sectors there is a great complexity in the evaluation of costs and revenues, this occurs mainly in public entities.

In view of the above, it is considered necessary a cost system that provides a better use of information and 
optimizes the use of resources, promoting the emergence of alternatives more appropriate to the financial strategies outlined. Brazilian law requires that public entities assess their costs, demonstrate efficiency and present the economic results of their activities. The Art. 1, § 1 of the Fiscal Responsibility Law Complementary Law 101/2000 establishes that the public service has a responsible and transparent fiscal management, enabling the achievement of income targets between revenues and expenses and compliance with limits and conditions established by it, one of the tools for management control and transparency of services is cost accounting.

As we saw the need to comply with legislation through a system of costs in hospital institutions, the following question is asked: The Hospital Colônia do Carpina complies with what is determined by $\S 3$ of article 50 of LC 101/2000 (Law of Fiscal Responsibility), which states that public administration will maintain cost systems that allow the evaluation and monitoring of budgetary, financial and asset management?

Seeking to answer the problematic one has as general objective to analyze if the HCC in Parnaíba uses the costs calculated in the exercises, as advocated by the LRF, as a managerial tool in its decision making process. Thus, to guide the general objective, the following specific objectives were outlined: Identify the use of a cost system in the HCC management decision-making process; Establish the level of information generated by accounting for internal control of the entity; To deepen the general notions of costs in hospital environments; and Study the LRF regarding the instrumentation of cost tools in management decisions.

The work is structured in three chapters. The first chapter, entitled Theoretical Rationale, discussed the literature review carried out during the research and presenting the authors' expression about the origin of accounting their basic concepts, methods of costing and accounting in the public sector and in hospital environments. In the second one it contains information about the methodology used to ascertain the cost concepts and the data collection of the hospital, and in the third chapter the results of the study are presented: the presentation of the hospital and the analysis of the data.

\section{THEORETICAL FOUNDATION}

\subsection{Cost accounting source}

For Martins (2010), until the Industrial Revolution (séc. XVIII) there was almost only financial or general Accounting, which was sufficient to serve the commercial enterprises of the Mercantilist Age. However, with the advent of industries, it became difficult for accountants to easily identify inventory values ??to close their balance sheets.

With the growth of the industry, accounting procedures had to be adapted to the new information demand. Martins (2010) expresses that the need to attribute values ??to the companies' inventories, at the time of closing the balance sheet and calculation of the result, led to the appearance of cost accounting.

Cost Accounting, initially, was limited to the function of evaluating the inventories of these industries and determining their results. With the complexity of the operations Accounting has evolved, adding new functions: control and the aid for decision making (MARTINS, 2010). 
Regarding the control Martins (2010 p.21) states that:

Its most important mission is to provide data for the establishment of standards, budgets and other forms of forecasting and, at an immediately following stage, to monitor the actual event for comparison with the previously defined values.

With the 2nd Industrial Revolution and the growth of the technology of the industries appeared the need to manage the organizations. Thus accounting gained strength by developing specific areas such as financial accounting and managerial accounting, assisting companies in their management.

These areas of accounting began to assist in the management of companies, since they provided information that was necessary for the control and planning of organizations, besides assisting managers through the measurement of financial information (SOUZA, 2008). Financial accounting, managerial accounting and cost accounting provide companies with help in decision making by generating good results, since one of the functions of accounting is to provide useful information about the patrimonial phenomena occurring in an entity.

From the adaptation and definition of procedures came the Accounting of Costs. Viceconti and Neves (p.6, 1998) highlight:

In its early days, Cost Accounting was mainly concerned with the valuation of inventories in industrial companies, which is a much more complex procedure than in commercial ones, since it involves much simpler purchase and resale of goods. Payments are made to factors of production such as wages, purchases and use of raw materials, etc.

In view of its strategic position in the accounting information system, the role of cost accounting has gained importance in the decision-making sphere of all organizations, as it acts as a source for the Financial Accounting, which prepares the financial statements, and the Managerial Accounting, which provides information related to the accounting data to its users (BRITO, 2002).

The costs are established so that the objectives can be reached in the determination of the profit, the control of the operations and the decision making. In addition to these objectives, the information generated by cost accounting subsidizes the determination of the costs of inputs used in production; the determination of the costs of the various areas that make up the company; the policies of reduction of the costs of the inputs applied in the production or the several areas that compose the company; control of operations and activities; the administration, assisting it in making decisions or solving special problems; the policies of reducing waste of material, idle time among others, the preparation of budgets (MEGLIORINI, 2007).

\subsection{Basic Concepts of Costs}

Cost accounting is the area of ??accounting science that devotes to the study of expenses incurred in the production of either a good or services. Its application can be done in any company since it has the intention to improve its controls, remaining actively in the market (FERREIRA, 2007).

Cost accounting is used to determine the costs of products or services and has an important role to play in 
providing decision-making information as it analyzes the entity's expenditure.

Leone (2000) defines Cost Accounting: "Cost Accounting is the branch of Accounting that is designed to produce information for the various managerial levels of an entity, such as aiding the functions of performance determination, planning and control of operations and decision-making ".

The terms used in Cost Accounting can be confused because the words are synonymous, but they have different meanings, there is no legal standard and the most common terms are: expense, cost, expense, investment, loss. The most confused terms are: cost, expense, and expense; and investment disbursement.

\subsubsection{Expenditure}

Expenditure is a sacrifice that the entity derives from the purchase of a product or service and is represented by the delivery or promise of a portion of the asset. The expense can be a cost, investment or expense. Martins (2010) defines expenditure as: purchase of any product or service, which generates financial sacrifice for the entity (disbursement), a sacrifice represented by delivery of assets (usually cash). Examples of expenses include the purchase of raw materials, expenses with board fees, hiring of various services, etc.

\subsubsection{Expenditure}

According to Martins (2010) expenditure refers to expenses with good or service consumed directly or indirectly to obtain revenues. Usually these activities are classified as commercial, administrative or financial expenses. Example: Selling expenses.

Megliorini (2007) points out that the expenses "correspond to the share of the expenses consumed to manage the company and realize the sales, that is, to generate the revenue".

Martins (2010) states that expenditures are items that reduce Shareholders' Equity and that have this characteristic of representing sacrifices in the process of obtaining revenues.

\subsubsection{Disbursement}

Disbursement corresponds to the payment on the acquisition of a good or service that was acquired, regardless of the moment it is consumed, and may occur before, during or after the input of the utility purchased (MARTINS, 2010).

It should be noted that the events occurring are accounted for on an accrual basis. Examples of disbursement: purchase of raw materials in sight; payment of bank loans, etc.

For Crepaldi (2004), "is the payment of the purchase of a good or service." It is the financial output of the company.

\subsubsection{Investment}

Investment is the assets of the entity, for MARTINS (2010) investment is characterized as the expenditure 
activated as a function of its useful life or benefits lagged or not at the time of expenditure.

Depending on their nature and the periods of activation, investment can be characterized as an expense that turns into investment and may be either current or permanent.

For Megliorini (2007, page 7), investments:

correspond to the portion of expenses recorded in company's asset accounts. They may refer to the acquisition of raw materials, goods for resale and miscellaneous materials (recorded in their respective inventory accounts), the acquisition of machinery or vehicles or even the acquisition of shares of other companies.

\subsubsection{Loss}

The loss is characterized by something unexpected, are not regular, are abnormal expenses, contributing to the generation of injury. It is a good or service consumed abnormally and involuntarily. (MARTINS, 2010)

Some examples: strikes, fires, theft leakage of liquid or gaseous materials; material with expired validity, etc.

\subsubsection{Waste}

It is considered wasteful activities that do not add value to the company, generating cost for company, lost time and not making a profit. Some examples: manufacturing defects; maintenance of unnecessary stocks, etc.

\subsection{Cost classification}

They can be classified as to their allocation of costs to products, these being direct and indirect, as well as their dependence on the volume of production or sale, fixed and variable, semi-fixed and semi-variable.

\subsubsection{Direct and indirect costs}

Direct costs are objectively appropriable to the finished product, which we can directly identify that this or another product belongs to, just having a measure of consumption. Examples: Raw material (direct material), packaging, etc.

Indirect costs are those that can not be directly appropriated to the products, in which the use of devices is used to allocate costs, that is, in an estimated way. Examples: factory rent, factory insurance, etc.

For MARTINS (2010) the classification of direct and indirect is with respect to the product made or the service provided, and not to production in the general sense or to departments within the company.

\subsubsection{Fixed and variable costs}


Another classification is fixed costs, which are those that do not depend on the volume that is produced, its amount is fixed depending on the number of activities. Examples: depreciation, rent, etc.

Depending on the volume of production, the variable costs are also classified, which are those that vary according to the volume of activity of the company, that is, the larger the quantity that is produced, the greater the consumption. Examples: Raw Material, Direct Material and Direct Labor, etc.

\subsection{Cost accumulation systems}

Depending on the nature of manufacturing, accumulation systems can be classified in two ways: by order or process. However, the way it will be depends on the client, to know how the process will be approached in relation to what is expected to be achieved and what has been achieved.

The accrual system by order costs are accumulated to meet a particular specific order or service order. SLOMSKI (2005) states that when starting work to meet the customer's request, start up in the process of accumulation of costs by order, and at the end of production will be accumulated all costs related to the products or services requested by the customer, regardless of the elapsed time.

To calculate this system, raw materials, direct labor and other costs must be aggregated. The unit cost of each order will be equal to the total cost divided by the unit number.

In the case of a process accumulation system, the resources consumed depend on the production time, that is, the customer stipulates a time period for the production time, and at the end of the period, the number of finished items is determined and the number of finished items are under development.

\subsection{Costing Methods}

According to Slomski (2005), costing is understood as the form of attribution of costs to a given product or service. According to Moreira et al (2004) method is the mechanism that defines the costs that will be part of the cost of the product or service, and system is the way of measuring each component of the cost.

The process of costing products or services in companies depends on the system and the costing method, because for each system and method used can achieve different values ??and structures. The choice of method should be supported by the availability of information and the volume of resources needed to obtain the information. Entities may adopt more than one costing methodology, depending on the characteristics of the costing objects and the objective to be achieved.

The main purpose of any costing method is to determine the cost incurred in the process of producing goods or rendering services. The method used in the calculation is determined according to the type of information that the entity needs in the decision making (PEREZ JUNIOR; OLIVEIRA; COSTA, 2008).

In determining the cost, the result is to associate to the products and services the expenses related to the activities of execution of goods and services that occur in the area of ??elaboration, which are considered departments. (DUTRA, 2009).

\subsubsection{Absorption costing methods}


Passarelli et al (2003, p.40), where these fixed costs are attributed by criterion, is the method that when the cost of products manufactured by the company are distributed to these products, besides variable expenses, of apportionment.

Martins (2010) states that this method of costing is derived from the application of generally accepted accounting principles, is not a principle in itself, but a methodology derived from them.

Martins (2010 p.168) states:

It is seen that the fiscal requires the use of Absorption Costing, so that all production costs, whether direct or indirect, are incorporated into the product. These items are those that the legislation determines are "obligatorily" aggregated, which does not mean an exhaustive and complete listing.

In accounting, all costs (fixed and variable, direct and indirect) are allocated to manufactured products and services, and direct costs are incorporated through direct and indirect appropriation through apportionment criteria.

According to Slomski (2005) direct costs are all production costs that are identifiable to the products and services without any method of cost allocation, that is, they are the costs that can be observed in the production process.

Indirect costs are all production costs that are not directly identifiable and thus some method of allocating these costs to products and services is necessary.

The absorption costing method is the most widely used method of calculating production costs in Brazil.

\subsubsection{Methods of Variable or Direct Costing}

According to Megliorini (2007), in this "costing method, the products will only receive the costs resulting from the production, that is, variable costs." And the fixed costs according to Martins (2010, p. 198) "are separated and considered as expenses of the period, going directly to the result."

Padoveze (2004) comments that:

Although it is usually called direct costing, the correct nomenclature is variable costing, because this costing method uses only the costs and expenses that have a proportional and direct relation with the quantity of products. The direct cost nomenclature comes from the fact that most variable costs are direct costs in almost all products.

According to Martins (2010), this method hurts accounting principles, especially that of Competence and Confrontation. According to these, we must appropriate the revenues and deduce from them all the sacrifices involved in their attainment. For that reason, it would not be correct to throw all the fixed costs on today's sales, if part of the made products will only sell tomorrow.

Thus, it is concluded that the variable cost of discarding the fixed costs of the products and counts them as expenses becomes a great ally to the manager in the decision-making, since it offers better 
management.

\subsubsection{Standard Costing Method}

According to Crepaldi (2012), Standard Cost is a cost established by the company as a goal for the products of its manufacturing line, taking into account the technological characteristics of the production process of each one, the quantity and prices of the inputs needed for the production and its volume.

This standard cost can be understood in several ways. In one of his understandings Martins (2010, p. 315) speaks of the Ideal Cost:

It would then be the value obtained by using the best possible materials, with the most efficient workforce, at $100 \%$ of the capacity of the company, without any stop for any reason, other than those already programmed due to a perfect preventive maintenance etc.

Time-of-production calculations would be made on the basis of minute timing and movement studies, with experiments using the best-qualified employee observed over a period of time, not considering their oscillating productivity during the day. That's why the idea of ??Ideal Standard Cost was born from an attempt to manufacture a cost in a laboratory. In the end, ideal standard cost would be a long-term goal of the company, not fixed for the next year or for a given month (Martins, 2010).

Another standard cost concept that is much more valid and practical is the Standard Cost of Ownership. Martins (2010 p.315) points out that:

This refers to the value that the company sets as the target for the next period for a product or service, but with the difference of taking into account the known deficiencies in terms of quality of materials, labor, equipment, supply of energy etc. It is a value that the company finds difficult to achieve, but not impossible.

Martins (2010) further defines that the main purpose of Cost-Standard, in the case of the most feasible Current, is cost control planning. After all, its main objective is to establish a basis for comparing what happened to costs and what should have happened, a method that can be used as an auxiliary technique.

\subsection{Public Sector Cost Accounting}

Cost accounting is an important tool in any type of organization, as it assists administrators in the decision-making process and expense control. In the public sector this is no different as an instrument that provides support for decision making, management control and transparency of the public service, as well as helping managers to manage efficiently and carry out effective public management. (MAUSS; SOUZA, 2008)

The use of a cost system in public administration was very limited, determining only the industrial public services, provided for in the Law 4,320 / 1964 in its article 99, in which the public entities had to maintain special accounting to calculate the costs of their services. Only in 1967 with Decree-Law no. 200 in its article 79 where the law determined for the whole public administration, that the costs of the services must be determined in such a way as to show the results of the management. 
For Slomski (2005, p.55) the application of a system of costs in the public administration is a new subject and is still in its "embryonic" phase. However, even with legislation "forcing" its use, it was not realized.

Legislation was not enough for Public Accounting to start producing information that would determine the costs of services. Article 79 of Decree-Law no. 200 was later regulated by Presidential Decree No. 93.872 / 1986, which outlined how accounting should determine the costs of services, and also punished those administrative management units that did not provide information for the disclosure:

Art. 137. The accounting should determine the cost of the projects and activities, in order to show the results of the management.

- 1. The calculation of the cost of projects and activities shall be based on the elements provided by the budget bodies, contained in the Project / Activity Budget Register, the use of the financial resources and the detailed information on the physical execution that the administrative management units shall to the respective accounting body, at the intervals established by the National Treasury Secretariat.

- $2^{\circ}$ The lack of information of the administrative unit on the physical execution of the projects and activities under its responsibility, in the established form, will entail the blocking of withdrawals of financial resources for the same projects and activities, being responsible for the lacking administrative authority for the resulting damages .

The creation of the LRF (LC $\mathrm{n}^{\circ} 101$, of May 4, 2000) brought a new interest to professionals, in its article 50, paragraph 3 stated: "The Public Administration will maintain a cost system that allows the evaluation and monitoring of the management budgetary, financial and patrimonial ".

In 2001 Law 10.180 / 2001 shows:

Art. 15. The purpose of the Federal Accounting System is to record the acts and facts related to the budgetary, financial and patrimonial administration of the Union and show:

$\mathrm{V}$ - the costs of programs and units of the Federal Public Administration;

The objective of the public sector is not to obtain profits, but to control costs, generating a better application of resources. A cost system allows the public sector a better decision-making result, in which it generates information so that the manager monitors the costs of goods and services, making operations more transparent so that society evaluates efficiency and effectiveness management of public resources.

The Federal Constitution also reinforces in its articles 37 and 70, that the public administration obey to the principles of efficiency and of economy, respectively.

The process of improvement in an organization calls for the use of an information system in which to support the decisions adopted. In 2009 Decree 6.976 in its art. 7 is responsible for the central body of the Federal Accounting System, which must maintain a cost system where it can evaluate and monitor budgetary, financial and asset management.

\subsubsection{Hospital cost system}


The role of cost management is a key tool for the elaboration of a strategic planning, as it provides managers with better information for decision making. According to Oliva (2004), several Brazilian hospitals, both in the private sector and in the public sector, saw the importance of using strategic planning and management as the basic principle for their development and growth.

Due to the diverse activities that are performed within a hospital, the cost system provides management with the best management to control their costs. And even with legislation requiring the implementation of a cost-effective system, few hospitals use it. For any entity, whether for profit or not, accounting information is an instrument for controlling and analyzing equity.

The users of accounting in the hospital seek solutions to help optimize the result, both the administrator, the funders and those who use the service seek to achieve efficiency in the activities. It also provides users with information about the data so that the services are provided at a considerable cost, so that it can avoid wastage by seeking improvement in the quality of services.

According to Falk (2001, p.15), the use of accounting systems in hospitals "provides important financial information for managerial analysis and strategic decision making".

The implementation takes the manager detailed information of each department, analyzes the costs with each patient, provides data and reports for the comparison of results with the goal of better management for decision making. And because of the complexity of the services that are provided within a hospital, it requires careful assessment of costs.

\section{RESEARCH METHODOLOGY}

According to Oliveira (1999), the methodology studies the means and methods of investigation of the correct and true thought whose function is to determine a specific problem, because as Macieira and Venture (2007) puts it, methods can be defined as the path by which one arrives to a certain result. In this context, all scientific research requires the use of methods, which for research must be chosen in such a way as to fulfill the intended objectives.

For Lakatos and Marconi (2006, p.15), research is a "formal procedure, with reflective thinking method, which requires scientific treatment and constitutes the way to know reality or to discover partial truths." It is fundamental in the field of social sciences, as it seeks solutions to the problems faced by society.

For research in the field of social science, specifically in research related to accounting, Beuren (2010) groups the typologies of research designs into three categories: regarding the objectives, the procedures and the approach to the problem.

Regarding the objectives presented, this research is classified as exploratory. According to Gil (2002, p. 41) this type of research has as its purpose the "improvement of ideas or the discovery of intuitions and aims to provide greater familiarity with the problem, with a view to make it more explicit or to constitute hypotheses" . We sought to present concepts related to the proposed theme through bibliographic research and to deepen the subject in the institution researched through an interview with the person responsible for the accounting sector. 
As a search procedure will be used bibliographic research. Santos (2000, p.29) defines this typology as:

set of written / recorded materials, mechanically or electronically, which contain information already elaborated and published by other authors, is a bibliographical form. Bibliographical sources are the bo[...] ]oks of symposium / seminar reports, annual congresses, etc. the total or partial use of any of these sources is what characterizes a bibliographical research.

According to Beuren (2010, page 86) the bibliographic research, "aims to gather information and prior knowledge about a problem for which the answer is sought." Another method used was the case study. This type is preferred by researchers who wish to deepen their knowledge about specific cases. (Beuren, 2010).

Gil (2006: 72) notes that:

The case study is characterized by the deep and exhaustive study of one or a few objectives, in order to allow its detailed and comprehensive knowledge, a task practically impossible by the other types of design considered.

Within the methodological procedures is done in the use of qualitative research that seeks a deeper analysis in relation to the phenomenon that is being studied. The qualitative approach seeks to highlight features not observed through quantitative studies. (Beuren, 2010)

The qualitative approach is presented by Fachin (2003, p.81) as:

Characterized by attributes and relates aspects not only measurable, but also defined descriptively. The set of values ??in which a qualitative variable is divided is denominated system of values. Such systems are not unalterable for each variable. Depending on the nature or objectives of the researcher or the techniques to be used, the variable deserves to be categorized.

The technique used in the case study was the application of a questionnaire that can be defined [...]as "an instrument of data collection, consisting of an ordered series of questions, which must be answered in writing"[...] (MARCONI \& LAKATOS, 2007, p. 203).

In the questionnaire we organize questions as a way of obtaining the necessary information for our work. We emphasize that the questionnaire has its own elaboration and application techniques for its validity, so it was elaborated with attention and according to the scientific norms.

\section{DATA ANALYSIS}

\subsection{Presentation of the Hospital}

According to Ruimar Batista (2010) leprosy reached Piauí from the process of settlement and Piauí colonization, but only in the twentieth century following the example of other states that the government and civil society sought to combat it. In 1822 there were already some cases of "leprosy" in the Province of Piauí. In 1924, the Apostleship of Charity built a house in the vicinity of Teresina, in order to accommodate those people who had contracted the disease, initially 3 people, but the place was home to 
16 people after the death of the last person who lived in the Teresian isolation and, by determination of the State Government, the place was later occupied by an airfield.

And in 1925, Souza Araújo estimated the existence of 100 cases of leprosy in Piauí. Knowing the existence of these cases, Dr. Mirócles Campos Veras with the support of his friends created the São Lázaro Foundation in the city of Parnaíba, whose objective was "to establish a colony and a hospital for the treatment of people affected by Hansen's disease." was nothing more than the application of the thought adopted by society at the time that defended the compulsory isolation, from the diagnosis, for people affected by leprosy. (Ruimar Batista, 2010)

The Hospital São Lázaro was inaugurated in July 1931 and officialized on August 24 of the same year by a Beneficent Society. On January 3, 1940, it was inaugurated by the State Government and from 1975 on it was called the Cologne hospital of Carpina. (Ruimar Batista, 2010)

The HCC is a Hospital-Colony, which housed and in the middle of the millennium hosts people who contracted leprosy. Some people have been living in the hospital for a number of years now, many people have been hospitalized to treat themselves and returned home, others have been abandoned by the family, and finally others are there because they do not have a family. (Ruimar Batista, 2010)

The HCC is a large terrain, but much larger. Currently, its physical part, about $2000 \mathrm{~m}^{2}$, was built on a large sandy land of about 40,000 $\mathrm{m}^{2}$ and is composed of several buildings, distant from each other, with 27 patients, but it even housed 300. There are 5 pavilions, 2 houses and several "patients" who live near the Colony are attended and seek medication in the Colony. (Ruimar Batista, 2010)

Ruimar Batista states "People are not there to be protected, but to protect society ... people who live there need health, work, education, leisure ... and citizenship, above all else. Discrimination, stigma and prejudice, the various problems that the people affected by leprosy in the Colony are concrete evidence that the Colonial Hospitals in the country are taken seriously and consequently the leprosy in the country has not been taken seriously. It is necessary for governments to take, do not say that they have the political will, but demonstrate with concrete actions that they want to end leprosy. "(2010)

\subsection{Analysis of hospital cost accounting}

Through the application of the questionnaire found that the hospital has a single accounting sector, which provides the cost information to the administration. This sector is responsible for monitoring all steps related to the execution of the expenditure, from its establishment, commitment, settlement and payment, in which it is carried out by the system used by the State to record the transactions, SIAFEM - Integrated Financial Management System for States and Municipalities.

The LRF establishes that public entities assess the costs of services, as required by law, so that it can evaluate the result of its management. The State itself is still initiating these new public accounting practices, even because the supervisory bodies themselves: the Piauí Court of Accounts - TCE-PI and the State Comptroller's Office charge nothing about it. The State Department of Health already speaks of adopting the use of costing systems, but has not yet offered training nor demanded that they be present in their organs. 
As shown in the tables below, a survey of revenues and expenses for the year 2012 is carried out, and we can observe all the monitoring of expenses and registration broken down into value and percentage.

Table 01 - Consolidation of Expenditure 2012

\begin{tabular}{|c|c|c|}
\hline Specification & Value & Total \\
\hline 3390.14 - Daily - Civil & $6,465.00$ & $6,465.00$ \\
\hline 3390.30 - Consumables & & $171,792.46$ \\
\hline Medication & $6,891.80$ & \\
\hline Material I think & $12,166.52$ & \\
\hline Food kinds & $113,300.83$ & \\
\hline Hygiene and cleaning supplies & $7,879.45$ & \\
\hline Mat. Cooking Gas & $5,180.00$ & \\
\hline Office supplies & $2,549.90$ & \\
\hline \multicolumn{3}{|l|}{ Refrigerator Parts } \\
\hline \multicolumn{3}{|l|}{ Electric material } \\
\hline Real Estate & $3,048.15$ & \\
\hline \multicolumn{3}{|l|}{ Clothing and uniforms } \\
\hline Cup and Kitchen Material & $2,920.00$ & \\
\hline \multicolumn{3}{|l|}{ Construction material } \\
\hline Spare parts for cars & $5,862.34$ & \\
\hline Fuel & $11,983.47$ & \\
\hline \multicolumn{3}{|l|}{ Manut. Machines } \\
\hline \multicolumn{3}{|l|}{ Mat. several } \\
\hline $\begin{array}{l}3390.33 \text { - Expenditure on passage } \\
\text { and locomotion }\end{array}$ & & - \\
\hline $\begin{array}{c}3390.36 \text { - Other Third Party } \\
\text { Services - Individuals }\end{array}$ & & $9,856.00$ \\
\hline \multicolumn{3}{|l|}{ Medical Productivity } \\
\hline INSS & 896.50 & \\
\hline Third Party Services & $8,959.50$ & \\
\hline \multicolumn{3}{|l|}{ Daily } \\
\hline 3390.37 - Renting of labor & & - \\
\hline $\begin{array}{c}3390.39 \text { - Other Services of Third } \\
\text { Parties - P. Jurídica }\end{array}$ & & $11,091.62$ \\
\hline
\end{tabular}




\begin{tabular}{|c|c|c|}
\hline telephone & $\mathbf{6 , 8 1 2 . 2 1}$ & \\
\hline Services Fee Adm. Ticket Car & $\mathbf{4 7 3 . 3 5}$ & \\
System & & \\
\hline Other Services & $\mathbf{3 , 6 0 0 . 0 0}$ & $\mathbf{2 , 1 2 2 . 6 0}$ \\
\hline Rate Detran & $\mathbf{2 0 6 . 0 6}$ & $\mathbf{-}$ \\
\hline Graphic services & & $\mathbf{2 , 1 2 2 . 6 0}$ \\
\hline 3390.92 - Expenses for prior & & $\mathbf{1 , 6 3 0 . 0 0}$ \\
\hline years & & $\mathbf{-}$ \\
\hline 4000.00 - CAPITAL & & $\mathbf{-}$ \\
\hline EXPENDITURE & $\mathbf{1 , 6 3 0 . 0 0}$ & $\mathbf{2 0 2 , 9 5 7 . 6 8}$ \\
\hline 4400.00 - INVESTMENTS & & \\
\hline 4490.57 - INSS Employers & & \\
\hline Material & & \\
\hline TOTAL & & \\
\hline
\end{tabular}

Source: Hospital Colônia do Carpina 2012

It is observed that in the nomenclature during the year, everything was considered expense, but among accounts broken down according to accounting terminology all are spent, others are costs and other expenses.

\section{Despesas HCC 2012}
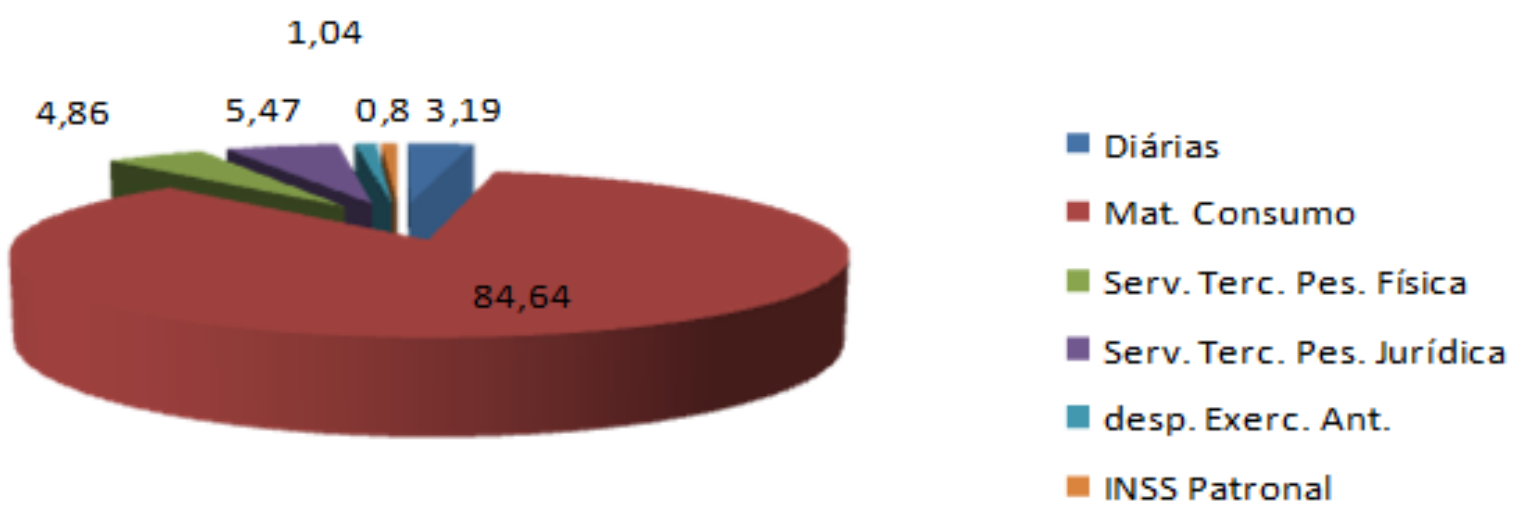
Graph 01 - Consolidation of Expenses 2012. SOURCE: Hospital Colônia do Carpina

We can see that among all the services provided by the HCC of all cats the highest cost for the hospital is with Consumer Material which represents $84.64 \%$, of the Consumption Materials the cost of greater significance are with Foodstuffs which represent 55, 8\%.

Table 02 - Consolidation of Revenues 2012

\begin{tabular}{|c|c|}
\hline Specification & Value \\
\hline \multicolumn{2}{|l|}{ 1. PREVIOUS YEAR BALANCE } \\
\hline \multicolumn{2}{|l|}{ 1.1 BOX } \\
\hline 1.2 BANK C / C No. 19302-X & 197.02 \\
\hline \multicolumn{2}{|l|}{ 1.3 BANK C / APPLICATION N ${ }^{\circ}$} \\
\hline \multicolumn{2}{|l|}{ 2. OPERATING INCOME } \\
\hline \multicolumn{2}{|l|}{ 2.1 SESAPI / Costing-Maintenance } \\
\hline \multicolumn{2}{|l|}{ 2.2 SESAPI / Capital-Investment } \\
\hline \multicolumn{2}{|l|}{ 2.3 AGREEMENTS, AGREEMENTS AND } \\
\hline \multicolumn{2}{|l|}{ CONTRACTS } \\
\hline 2.3.1 SUS / Hospital Care & 210,383.37 \\
\hline \multicolumn{2}{|l|}{ 2.3.2 SUS / Ambulatory Care } \\
\hline \multicolumn{2}{|l|}{ 2.3.3 IAPEP } \\
\hline \multicolumn{2}{|l|}{ 2.3.4 Other (Specify) } \\
\hline \multicolumn{2}{|l|}{ 2.4 PAYING PATIENTS } \\
\hline 2.5 FINANCIAL APPLICATIONS & 102.99 \\
\hline \multicolumn{2}{|l|}{ 2.6 MISCELLANEOUS (Specify) } \\
\hline $2.6 .1 \ldots \ldots \ldots \ldots$ & \\
\hline TOTAL. & $\mathrm{R} \$$ \\
\hline
\end{tabular}

Source: Hospital Colônia do Carpina 2012

With this table 2, we can see that the main income of the hospital comes from the Unified Health System, and that HCC brought a positive balance from the previous year.

Table 04 - Number of Outpatients, Hospitals and Emergencies 2012 


\begin{tabular}{|c|c|c|}
\hline \multirow{2}{*}{ Months } & Ambulatory & Internment \\
\cline { 2 - 3 } & No. of Pac. Attended & No. of Pac. Attended \\
\hline January & 866 & 27 \\
\hline February & 626 & 27 \\
\hline March & 574 & 22 \\
\hline April & 465 & 19 \\
\hline May & 595 & 21 \\
\hline June & 653 & 25 \\
\hline July & 656 & 26 \\
\hline August & 735 & 25 \\
\hline September & 687 & 25 \\
\hline October & 640 & 15 \\
\hline November & 633 & 18 \\
\hline December & 588 & 19 \\
\hline Total & $\mathbf{7 . 7 1 8}$ & $\mathbf{2 6 9}$ \\
\hline
\end{tabular}

A total of 269 (two hundred and sixty-nine) internal patients were treated at a total annual cost of two hundred and two thousand nine hundred and fifty-seven reais and sixty-eight centavos ( $R$ \$ 202,957.68), which shows an annual per capita cost of $\mathbf{R} \mathbf{\$} \mathbf{7 5 4 . 4 9}$ (seven hundred and fifty-four reais and forty-nine cents). In this case, the absorption cost method was used, where in accounting all costs (fixed and variable, direct and indirect) are allocated to services rendered, and direct costs are incorporated through direct appropriation.

Whenever it is necessary to carry out a bidding for the purchase of foodstuffs, medicines or hospital dressings, the accounting department does a cost survey and payment capacity, based on this information if you are aware of how much you can bid or if you need to do something the amount to be acquired.

The HCC, whenever it needs to know the costs, uses the absorption method, which, according to Martins (2010, p. 38), is a "basic" method and "often fails as a management tool". In addition to this method being basic the way it is being used is not efficient, especially when it is analyzed from the managerial point of view.

Critics of the absorption cost method condemn its use because they consider that the apportionment is arbitrary, which does not correctly identify the cost to be attributed to the product or serum produced.

ABC, as Slomski (2005, p. 85) states, "is the one that applies most to the public entity of direct administration, since it is a habit in these institutions to define activities, since the public budget is structured in programs, projects and activities. " Advocates of the ABC method believe that activities, 
actions developed that actually consume resources.

\section{CONCLUSION}

Even with the importance of using an information system that allows the provision of data needed to better manage the decision-making process, as advocated by the LRF. The study analyzed the information provided by the HCC accounting industry and it was noted that the hospital administration is not aware of the RFL and that the entity uses a cost system in its decision making process, but this is still not satisfactory.

HCC uses a system to record transactions, but it is not able to provide and generate information for administrative decisions and control of its resources. The calculation of your expenses and the information that is generated is obtained through consolidations of expenses and revenues.

The study showed that the tool used by the accounting sector does not generate cost information that is capable of ascertaining and evaluating the monitoring of the budgetary, financial and equity management of the entity.

An approach on costing methods was made in the theoretical framework, confirming in the entity an existing, even if not satisfactory, type of method.

The standard costing method can be used as an auxiliary technique, which is used together with another costing method, which is judged to be more efficient by management, become a powerful decisionmaking tool, and accompany budgetary, financial and patrimonial

These are management tools that are able to generate information in order to reduce the costs of services without losing quality competence.

Finally, working within what the current tax legislation governs is still far from reaching a consensus of the public administration. However, the FRL has been in force for almost fourteen years, which makes matters necessary and urgent.

\section{REFERENCES}

BRAZIL. Complementary Law No. 101 of May 4, 2000. It establishes public finance standards for fiscal responsibility and provides other measures. Official Journal of the Union of 05.05.2000. Brasília, 2000. Available in: <> Accessed on: May 21, 2017.

BRAZIL. Complementary Law No. 4,320 of May 17, 1964. Estatui General Standards of Financial Law for the preparation and control of budgets and balance sheets of the Union, the States, the Municipalities and the Federal District. Official Journal of the Union (s / d). Brasília. Available at: <http://www.planalto.gov.br/ccivil_03/leis14320compilado.htm> Accessed on: 20 May 2017.

BRAZIL. Decree-Law No. 200 of February 25, 1967. It deals with the organization of the Federal Administration, establishes guidelines for Administrative Reform and makes other provisions. Available at: <http://www.planalto.gov.br/ccivil_03/decreto-lei/de10200.htm> Accessed on: 19 May 
2017.

BRAZIL. Decree-Law no. 93,872 of December 23, 1986. It provides for the unification of the cash resources of the National Treasury, updates and consolidates the pertinent legislation and gives others Available in: <http://www.planalto.gov.br/ccivil_03/decreto-lei/de10200.htm> Accessed in: 19 May 2017.

VICECONTI, Paulo Eduardo V .; NEVES, Silvério das. Cost Accounting: a direct and objective approach. São Paulo: Sentence, 1998.

MARTINS, Eliseu. Cost Accounting. 9 ed. São Paulo: Atlas, 2006.

SLOMSKI, Valmor. Controllership and governance in public management. São Paulo: Atlas, 2005.

SILVA, Ana Rachel de Carvalho Silva, BRITO, Carlos Alberto Oliveira Brito. Hospital cost management: a case study at Inácia Pinto dos Santos Hospital - Feira de Santana - BA available at http://portal.ftc.br/eventos/wie/2012/artigos/3\%20-\%20Gest\%C3\% 20\% 20\% 20\% 20\% 20\% 20\% 20\% 20\% 20\% Hospital\% 20In\% C3\% A1cia.pdf Access on 06/14/2017.

BRAZIL. Complementary Law No. 101 of May 4, 2000. It establishes public finance standards for fiscal responsibility and provides other measures. Official Journal of the Union of 05.05.2000. Brasília, 2000.

BRITO, Carlos Alberto Oliveira. A contribution to the process of allocation of joint costs in the beef slaughtering industry: a case study. 2002. 102 f. Dissertation (Masters) - Foundation Visconde de Cairú, Salvador, 2002.

MAUSS, Cezar Volnei; SOUZA, Marcos Antonio De. Cost management applied to the public sector: a model for measuring and analyzing government efficiency and effectiveness. São Paulo: Atlas, 2008.

MEGLIORINI, Evandir. Costs: analysis and management. 2. ed. - São Paulo: Pearson Prentice Hall, 2007.

${ }^{[1]}$ Graduate in Accounting Sciences

${ }^{[2]}$ Graduate in Accounting Sciences

${ }^{[3]}$ Graduate in Accounting Sciences

${ }^{[4]}$ Tourist, PhD student in Geography, professor at the Federal University of Piaui.

${ }^{[5]} \mathrm{PhD}$ in Psychoanalysis, management specialist and researcher at the Center for Research and Advanced Studies - CEPA 
Revista Científica Multidisciplinar Núcleo do Conhecimento - RC: 12547 - ISSN: 2448-0959

https://www.nucleodoconhecimento.com.br/business-administration/management-of-costs-in-administration-public

\section{PUBLIQUE SEU ARTIGO CIENTÍFICO EM:}

https://www.nucleodoconhecimento.com.br/enviar-artigo-cientifico-para-submissao 